\title{
Social Media, Pre-Teenagers and Fashion Consumption: Influence and Consequence
}

\author{
Emily Caroline Santos Miyagawa, Fernanda Barbi Brock, Fátima Cruz and Adriana Yumi Sato Duarte* \\ Faculty of Communication, Arts and Design, Nossa Senhora do Patrocinio University, Brazil
}

*Corresponding author: Adriana Yumi Sato Duarte, Faculty of Communication, Arts and Design, Nossa Senhora do Patrocinio University, São Paulo, SP, Brazil.

Received Date: July 19, 2019

Published Date: July 22, 2019

\section{Opinion}

Over the years, pre-teenagers have undergone significant changes in their habits, tastes and daily life. The current generation experiences the advancement of technology since birth and cannot imagine what life would be like without the internet.

The pre-teens ( 8 to 12 years) are always looking for innovation, technology and comfort. This generation was born in a connected age, in which through social media and series they learn that they can be and live in another reality. In today's world, this group actively uses all the social media websites, and they possess a strong power to influence their parents to buy what they want [1].

Social media are collaborative communication platforms, where users can create profiles and post photos, music, videos and texts, exchange information, make friends, among other possibilities [2]. In complement, [3] points that these platforms create a new environment that is changing the way people communicate, interact and socialize.

Digital influencers use artifices such as charisma and interaction to keep the audience and stay on top of the rankings, to become one of the main opinion formers and to profit from sponsoring brands and services. According to a survey, 35\% of followers of digital influencers claim to have engaged in some kind of cause by reposting them in their networks and $70 \%$ of teens who access YouTube prefer digital influencers than celebrities [4].

Digital influencers can be classified through three aspects: coverage, relevance and resonance. Coverage is related to the followers' quantity; resonance means engagement and relevance is the importance of what is published. They cultivate a sense of intimacy, accessibility, and relatability, which are the foundation for affective relationships with followers [5]. Thus, digital influencers are presented as the new idols of future generations that form opinions that determine and influence the decisions of their public when buying a specific product or service, and even in the way of dressing and acting [6].

The fashion consumption is in line with this context. Pre-teens' taste, preferences and identities are shaped by the media and popular culture. This group present greater involvement in and control over the decision-making and purchasing processes [7].

Our research on the parents' view about pre-teens' preferences showed elements that can be added in this discussion. In a preliminary study with 25 parents, it was noticed that parents no longer buy clothes by themselves; their kids participated in this process. They also believe that pre-teens are interested in fashion and can choose their own clothing. One of the most interesting data is that almost $80 \%$ of the respondents agree that technology influences their kids' opinions.

From the literature and our preliminary study, we noticed that technology and social media affect directly pre-teens' opinions and point of views, especially in fashion consumption. There are advantages and disadvantages of this new way of communicating and socializing; on the one hand pre-teens access unlimited amount of information that can be easily and quickly found [8], on the other hand, due to the intensive exposition to negative information, their Internet and social networking usage interferes with their daily lives [9]. Whether positive or negative, it is undeniable that social media occupy a huge part of modern life.

\section{Acknowledgement}

The authors thank the respondents of our questionnaire and the Nossa Senhora do Patrocinio University.

\section{Conflict of Interest}

The authors declare no conflict of interest. 


\section{References}

1. Francesco M (2012) Consumo Autoral: As gerações como empresas criativas ( $2^{\text {nd }}$ edn) São Paulo: Estação das Letras e Cores. pp. 254-259.

2. Vinicius G (2018) 0 que são Redes Sociais. Apresenta definição do que são as redes sociais.

3. Mustafa E (2019) Social media and children. In: Handbook of Research on Children's Consumption of Digital Media. IGI Global, p. 11-23.

4. Allison + Partners (2017). Influence 360.

5. Kelley C (2019) Playing the visibility game: How digital influencers and algorithms negotiate influence on Instagram. New Media \& Society 21(4): 895-913.
6. Sommer K, Silvera DH (2016) From digital media influencers to celebrity endorsers: attributions drive endorser effectiveness. Marketing Letters 27(3): 553-567.

7. Maria P (2010) Children and fashion. Understanding children and consumers. P. 202-217.

8. Shin W (2015) Parental socialization of children's Internet use: A qualitative approach. New media \& society 17(5): 649-665.

9. Rial A, Golpe S, Isorna M, Braña T, Gómez P (2018) Minors and problematic Internet use: Evidence for better prevention. Computers in Human Behavior 87: 140-145. 